\title{
Light-induced shell pigmentation in post-larval Mytilus edulis and its use as a biological tag
}

\author{
George A. Trevelyan, Ernest S. Chang* \\ University of California, Bodega Marine Laboratory, PO Box 247, Bodega Bay, California 94923, USA
}

\begin{abstract}
It was found that shell pigmentation in post-larval $(<1.5 \mathrm{~mm}$ ) Mytilus edulis $\mathrm{L}$. is controlled by light intensity. This relationship was used to develop a method for tagging cohorts of these post-larvae. It was also used to infer the light regime experienced by wild post-larvae in the field. Growth was temporarily slowed during the light phase of the tagging process. No effect of the tag on subsequent survival was seen. Since the tag consists of a pigment band in both the periostracum and the prismatic shell layers, it persists until these layers erode away. The utility of the tag in a field trial is described.
\end{abstract}

\section{INTRODUCTION}

The young post-larvae of marine invertebrates are typically very small and inconspicuous, making measurements of mortality rates and movements difficult. Consequently, little is known of their ecology and behavior in the field. The development of molluscan hatchery technology, however, has made it possible to obtain large numbers of newly metamorphosed postlarvae of known species. These post-larvae can be transplanted and manipulated in different field situations. This 'seeding' approach can facilitate investigations of post-larval ecology in natural or cultivated ecosystems.

To keep track of cohorts seeded in a habitat, tagging is often necessary. A number of methods have been developed to tag molluscan post-larvae. Dey \& Bolton (1978) showed that the American oyster Crassostrea virginica and the hard clam Mercenaria mercenaria could be tagged using the antibiotic tetracycline, which fluoresces under ultraviolet light. However, they found that the tetracycline tag was ambiguous in Mytilus edulis. Larval and post-larval bivalves can also be marked with the vital stain alizarin sodium monosulfonate (Hidu \& Hanks 1968). The growing bivalve incorporates this stain into newly produced shell, resulting in an easily seen and persistent band of reddish shell.

\footnotetext{
- Addressee for correspondence
}

Another tagging approach is to manipulate the algal diet, which is known to influence shell color in several gastropods such as Haliotis spp. and Turbo spp. (reviewed by Olsen 1968). For instance, in H. rufescens, red algae cause the secretion of a red shell while brown and green algae produce white or light green or blue shell. Tegner (1987) found that because of this effect of diet on shell color, hatchery-produced abalone seed reared on a diet of diatoms or brown algae could be distinguished from wild seed, which is almost always reddish in color.

Genotypic shell polymorphisms have also been employed as biological tags. Chanley (1961) investigated the inheritance of the distinctive shell markings exhibited by the notata subspecies of Mercenaria mercenaria. Field plantings of this subspecies can be distinguished from naturally recruited individuals, which usually lack these markings ( $R$. Kraus pers. comm.). Unlike the other tags which eventually erode away, the genetic tag is continually produced as the individual grows.

Seed (1969) grew Mytilus edulis (initial mean length $17.5 \mathrm{~mm}$ ) in darkness and in light and found that the shell secreted in darkness was yellowish brown in color, while that secreted in the light was blacker. In our attempts to find a tagging method for $M$. edulis, we further investigated the effects of light on pigmentation in post-larval mussels and its potential for creating recognizable bands. 


\section{MATERIALS AND METHODS}

Production of post-larvae. Mytilus edulis L. (black morph) adults were spawned using heat shock and the larvae were reared in $200 \mathrm{l}$ tanks following the methods of Loosanoff \& Davis (1963), Bayne (1965), and Trevelyan \& Chang (1983). Settlement and metamorphosis were induced by air-lift pumping of the larval culture into and through a basket at the tank surface containing thalli of the filamentous red algae Polysiphonia sp. and Ceramium sp. After 1 or $2 d$, the algae were manually broken up and shaken under water. This process dislodged most post-larvae out of the algae, allowing them to be collected for use.

Experiment 1: growth rates. This experiment compared the shell pigmentation and growth rates of postlarvae reared under bright light of 11000 to 16000 lux versus semi-darkness of 1 to 40 lux. The post-larvae used had a mean initial length of $0.9 \mathrm{~mm}$. Length was measured as the distance from the larval umbo to the posterior shell extremity. Each of the 55 post-larvae was reared in an individual $7 \mathrm{ml}$ dish $(1.5 \times 3.0 \mathrm{~cm}$, $\mathrm{h} \times \mathrm{d}$ ). These 55 dishes were fully submerged in $3 \mathrm{~cm}$ of seawater in a $16 \mathrm{l}$ tank $(30 \times 183 \mathrm{~cm})$. Thirty dishes were arranged at the light end of the tank and 25 at the opposite end, which was dark. The 55 dishes took up $10 \%$ of the bottom surface area of the tank and were 3 to $5 \mathrm{~cm}$ apart. A fluorescent light fixture $1.5 \mathrm{~m}$ long with dual $40 \mathrm{~W}$ tubes) was placed $2 \mathrm{~cm}$ above the water surface. The dark end was lined and covered with opaque black plastic. Water was pumped out of this tank at $4.5 \mathrm{I} \mathrm{min}^{-1}$, through a cooling water bath, and back into the tank. Repeated measurements of algal density and temperature verified that this system prevented any significant differential heating or algal blooming in the 2 ends of the tank. The water was changed every 3 to $5 \mathrm{~d}$. The concentration of the algal food used, Isochrysis galbana-Tahitian Strain (T-ISO), averaged 100 cells $\mu \mathrm{l}^{-1}$. The temperature ranged from 17.3 to $23.5^{\circ} \mathrm{C}$ and averaged $19.7^{\circ} \mathrm{C}$. After $17 \mathrm{~d}$ the lengths of all post-larvae were measured to the nearest $20 \mu \mathrm{m}$ using a dissecting microscope at $50 \times$. On Day 17 the light was turned off and all post-larvae were reared in the dark for another $10 \mathrm{~d}$. Final lengths were then measured.

Movement of the post-larvae out of their dishes was inhibited if the post-larvae were initially allowed to attach their byssal threads to their dish for $1 \mathrm{~d}$ before immersing the dishes in the water bath. The day before the experiment began, therefore, the post-larvae were added to their separate dishes (containing $6 \mathrm{ml}$ of water), and allowed to attach. During the experiment, daily observations were made of the positions of the post-larvae. None of the dark treatment post-larvae left their dishes. However, there was some movement in the light treatment, with 12 of the 30 post-larvae leaving their dishes. These were excluded from the experiment.

Experiment 2: survival. This experiment compared the survival of tagged versus untagged post-larvae in the laboratory using a larger sample size ( $\mathrm{n}=388$ ) than used in Expt 1. As in Expt 1, all post-larvae (initial mean length $=0.5 \mathrm{~mm}$ ) were reared in the same tank with one group being exposed to bright fluorescent light, the other to semi-darkness. The light was left on for $4 \mathrm{~d}$. This was the length of time typically used to tag post-larvae. After this period, the 2 treatment groups were reared under dim light in separate 11 dishes for a further $26 \mathrm{~d}$, at which time survival and percent tagged was measured.

Routine tagging procedure. After metamorphosis, the post-larvae were reared in darkness to a length of 0.5 to $1.0 \mathrm{~mm}$. One wk after metamorphosis, a sheet of white PVC plastic $(28 \times 100 \mathrm{~cm})$ was positioned horizontally in a trough of seawater $(30 \times 180 \mathrm{~cm}) 1$ to $3 \mathrm{~cm}$ below the water surface. Between 10000 and 100000 post-larvae were then sprinkled over the $2800 \mathrm{~cm}^{2}$ of PVC sheeting. The next day, the sheet was removed from the water and those post-larvae which had crawled to the edges or underside were removed. The sheet was then replaced. At this time, 2 fluorescent light fixtures ( $1.5 \mathrm{~m}$ long with dual $40 \mathrm{~W}$ tubes), were positioned directly over the post-larvae, 2 to $4 \mathrm{~cm}$ above the water surface. Water was pumped out of the trough and through a cooling water bath and back into the trough. This kept the temperature between 17 and $21^{\circ} \mathrm{C}$ and also helped circulate water over the postlarvae. T-ISO was fed at approximately 125 cells $\mu \mathrm{I}^{-1}$. Incident light intensity was 11000 to 16000 lux. The growing post-larvae were held under this light for 4 to $5 \mathrm{~d}$ followed by 4 to $10 \mathrm{~d}$ of darkness. Between March 1985 and October 1986, this tagging procedure, with slight variations, was used 20 times to tag post-larvae from 7 different batches of larvae. Each of these batches was derived from a different group of parents which were collected from both Northern (Bodega and Tomales Bays) and Southern California (Santa Barbara)

Field trial. A group of approximately 19000 tagged post-larvae (mean length $=1.9 \mathrm{~mm}$ ) was allowed to attach to substrates (sections of woven fire hose) at a mean density of $41 \mathrm{~cm}^{-2}$. The total initial number of post-larvae was estimated using random quadrat sampling. These substrates were then attached to the underside of a plywood sheet which was floated on the water surface in 3 to $7 \mathrm{~m}$ of water in Marconi Cove on Tomales Bay, California, for $75 \mathrm{~d}$ (September to December 1985). After this time, the total number of mussels present was individually counted by breaking up the clumps and sorting. A sample of 809 of these 
mussels was collected randomly and each sampled mussel was examined for the presence or absence of a tag. In addition, the maximum length was measured to the nearest $0.1 \mathrm{~mm}$ with vernier calipers. Tags were recognized by their characteristic appearance (unpigmented shell on either side of the band) and by their location (about $1.0 \mathrm{~mm}$ from the umbo).

Pigmentation patterns of wild mussels. Between August 1985 and August 1986, 319 Mytilus edulis were collected from buoys, docks, rafts, and long lines in Bodega Harbor and Tomales Bay, California. These mussels ranged in length from 1.0 to $6.0 \mathrm{~cm}$, although the majority were small $(1.0$ to $3.0 \mathrm{~cm})$. Only mussels without erosion of the prismatic shell layer were used. We examined the umbos of each of these mussels at $12 \times$ under a dissecting microscope and measured (to the nearest $85 \mu \mathrm{m}$ ) the length in the direction of growth from the umbo of the larval shell (prodissoconch) to the beginning of any darkly pigmented shell. The occurrence of any band of pigmentation within $1.0 \mathrm{~mm}$ from the larval umbo was recorded.

\section{RESULTS}

\section{Experiment 1: growth rates}

Expt 1 examined the effect of fluorescent light on the shell pigmentation and growth rate of Mytilus edulis post-larvae. Fig. 1 shows post-larvae from Expt 1 that had been grown for $17 \mathrm{~d}$ under either semi-darkness (1 to 40 lux) (Fig. 1A) or continuous bright light (11000 to 16000 lux) (Fig 1B). All individuals grown under bright light secreted darkly pigmented shell over the $17 \mathrm{~d}$. The length of these post-larvae on Day 0 of this experiment could be determined from the length of the unpigmented shell. In contrast, all mussels grown under darkness secreted clear or nearly clear shell during the experiment. Since neither temperature nor algal concentration varied significantly between the 2 groups, the pigmentation response is attributable to light alone. Also seen in Fig. 1 are terminal byssal attachment plaques with short byssal hairs projecting from the shells of the post-larvae.

Growth data for these post-larvae from Expt 1 are given in Table 1. On Day 0, the light and dark groups were not significantly different in length, averaging $896 \mu \mathrm{m}$ (Student t-test; $\mathrm{t}=0.4, \mathrm{df}=41, \mathrm{p}>0.5$ ). During the $17 \mathrm{~d}$ experimental period the dark group grew significantly faster than the light group (Student $\mathrm{t}$-test; $t=2.5, d f=41, p<0.02)$. The mean growth rate of the dark group (41 $\mu \mathrm{m} \mathrm{d}^{-1}$ ) was $20.5 \%$ faster than that of the light group $\left(34 \mu \mathrm{m} \mathrm{d}^{-1}\right)$. During the $10 \mathrm{~d}$ subsequent to the experimental period, both groups of mussels were held in the dark. During this period, both groups showed rapid, though more variable growth, averaging $117 \mu \mathrm{m} \mathrm{d}^{-1}$. No significant difference in
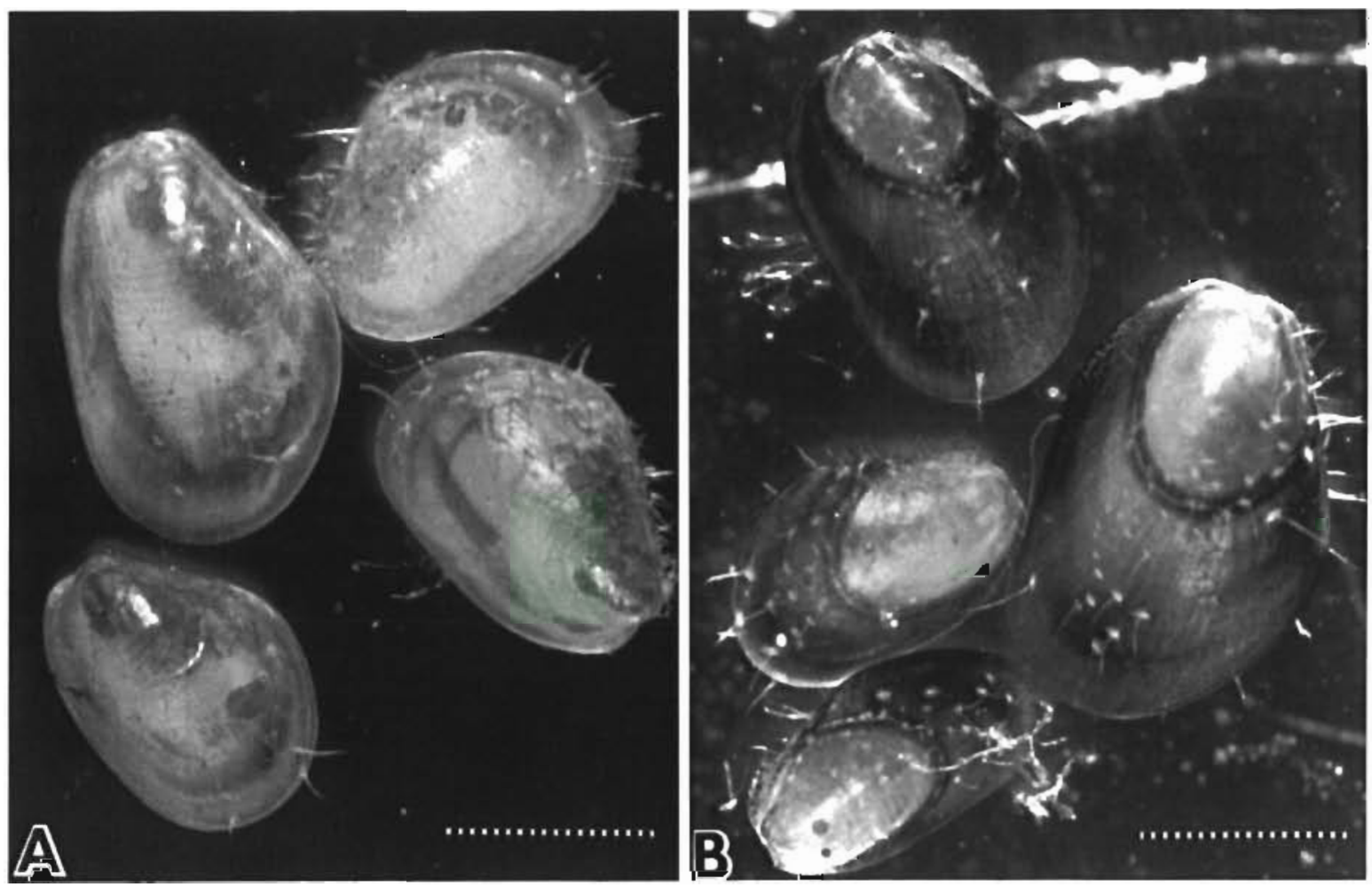

Fig. 1. Mytilus edulis. Post-larvae reared for $17 \mathrm{~d}$ under (A) semi-darkness (1 to 40 lux) or (B) continuous, bright (11000 to 16000 lux) fluorescent light. Bars $=1.0 \mathrm{~mm}$ 
Table 1. Mytilus edulis. Initial mean lengths and growth rates ( \pm SD) of post-larvae during an experimental period (Days 0 to 17 ) of either high (11000 to 16000 lux) or low (1 to $40 \mathrm{lux}$ ) light intensity and a subsequent control period (Days 18 to 27 ) of low light for both groups. Comparisons were made using Student t-test

\begin{tabular}{|c|c|c|c|c|c|c|c|c|c|}
\hline \multirow{3}{*}{$\begin{array}{l}\text { Light treat- } \\
\text { ment group }\end{array}$} & \multicolumn{3}{|c|}{ Initial length $( \pm \mathrm{SD})(\mu \mathrm{m})$} & \multicolumn{6}{|c|}{ Growth rate $( \pm \mathrm{SD})\left(\left\lfloor\mathrm{m} \mathrm{d}^{-1}\right)\right.$} \\
\hline & & & & \multicolumn{3}{|c|}{ Days $0-17$} & \multicolumn{3}{|c|}{ Days $18-27$} \\
\hline & $\overline{\mathrm{x}}$ & $\mathrm{n}$ & $\mathrm{p}$ & $\overline{\mathrm{x}}$ & $\mathrm{n}$ & $\mathrm{p}$ & $\overline{\mathrm{x}}$ & $\mathrm{n}$ & $\mathrm{p}$ \\
\hline High & $906 \pm 137$ & 18 & \multirow[b]{2}{*}{$>0.5$} & $34 \pm 10$ & 18 & \multirow[b]{2}{*}{$<0.02$} & $114 \pm 38$ & 16 & \multirow[b]{2}{*}{$>0.5$} \\
\hline Low & $890 \pm 122$ & 25 & & $41 \pm 8$ & 25 & & $119 \pm 51$ & 20 & \\
\hline
\end{tabular}

growth rates between the 2 groups was detected during this subsequent period (Student t-test; $t=0.3$; $\mathrm{df}=34, \mathrm{p}>0.5$ ). In contrast to the initial $17 \mathrm{~d}$ of the experiment, when dark-reared post-larvae produced transparent shell, new shell growth during the final $10 \mathrm{~d}$ in the dark did contain some lightly colored pigmentation. This began to occur as the post-larvae reached approximately 1.5 to $3.0 \mathrm{~mm}$.

\section{Experiment 2: survival}

This experiment compared survival between tagged and untagged mussels in the laboratory over a $30 \mathrm{~d}$ period. Of the tagged mussels ( $\mathrm{n}=234), 77 \%$ survived, compared to $78 \%$ survival for the untagged mussels $(\mathrm{n}=154)(\mathrm{p}>0.05)$.

\section{Routine tagging procedure}

Fig. 2 depicts the routine light banding process. Before exposure to bright light, the $0.8 \mathrm{~mm}$ post-larvae had a transparent shell (Fig. 2A). After $4 \mathrm{~d}$ in the light, the shell margins, where new growth had occurred, were pigmented (Fig. 2B). During the next $5 \mathrm{~d}$ in the dark, all new growth was once again unpigmented. This created a banded appearance (Fig. 2C). Fig. 3 shows larger mussels ( 7.0 to $10.0 \mathrm{~mm}$ in length) that had been retrieved after $1 \mathrm{mo}$ in Marconi Cove. Their bands are still easily seen. All of the 7 batches of postlarvae used in the tagging studies uniformly showed the light-dependent pigmentation response. The first attempts to tag large numbers of cohorts of post-larvae usually resulted in only 80 to $90 \%$ tagged. Untagged individuals appeared to be those shaded under clumps of other post-larvae or those that did not grow significantly. It was found that the percent tagged could be increased to greater than $95 \%$ by more uniform spreading out of post-larvae directly under the light source, and by extending the light phase to $5 \mathrm{~d}$.

The pigment bands produced actually consisted of a periostracal band of reddish-brown pigment overlaying
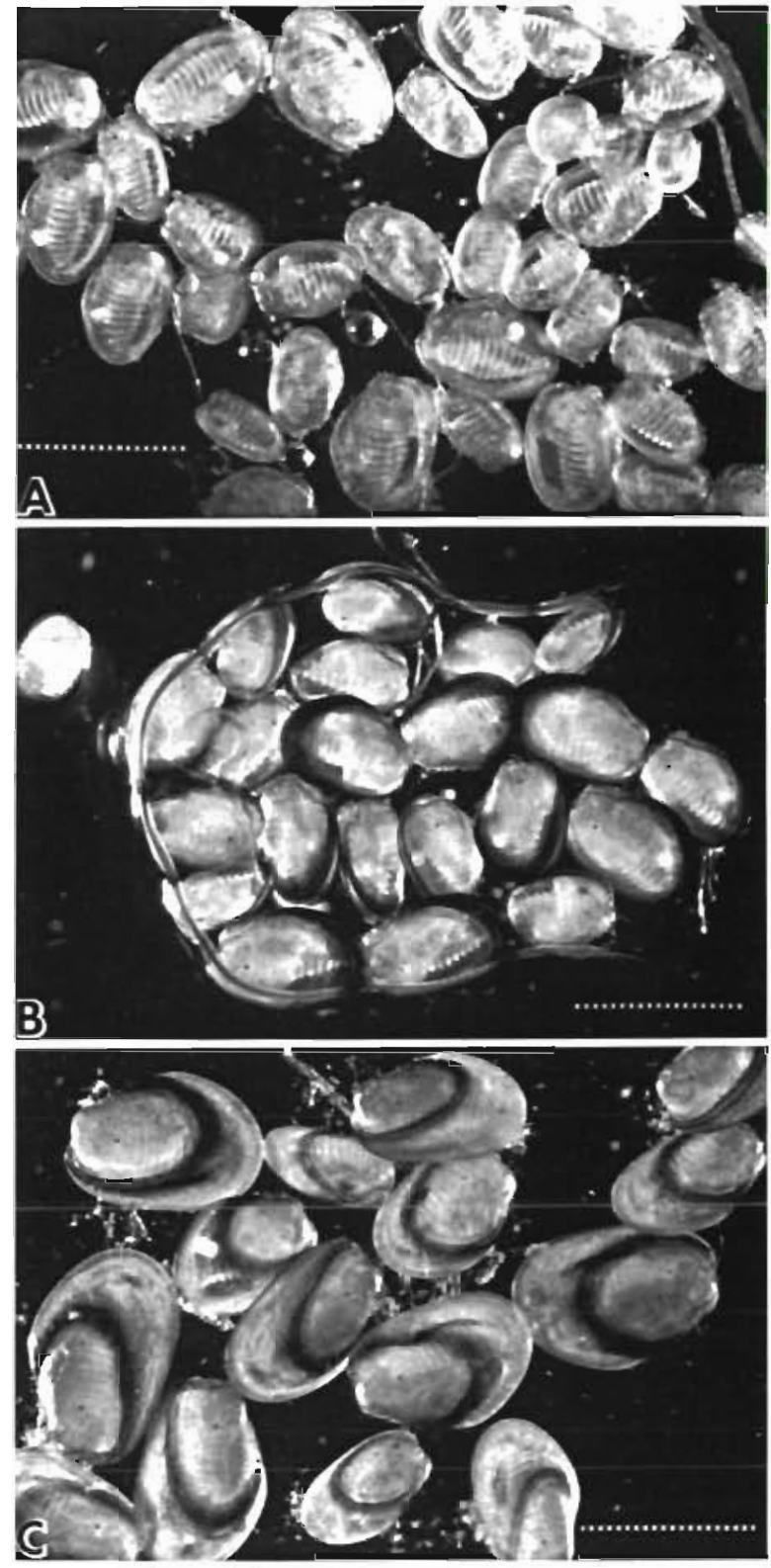

Fig. 2. Mytilus edulis at 3 stages of the tagging process: (A) immediately before rearing under light; (B) after being reared for $4 \mathrm{~d}$ under continuous, bright (11000 to 16000 lux) fluorescent light; and $(C)$ after a subsequent $5 \mathrm{~d}$ in the dark. All bars $=1.0 \mathrm{~mm}$ 


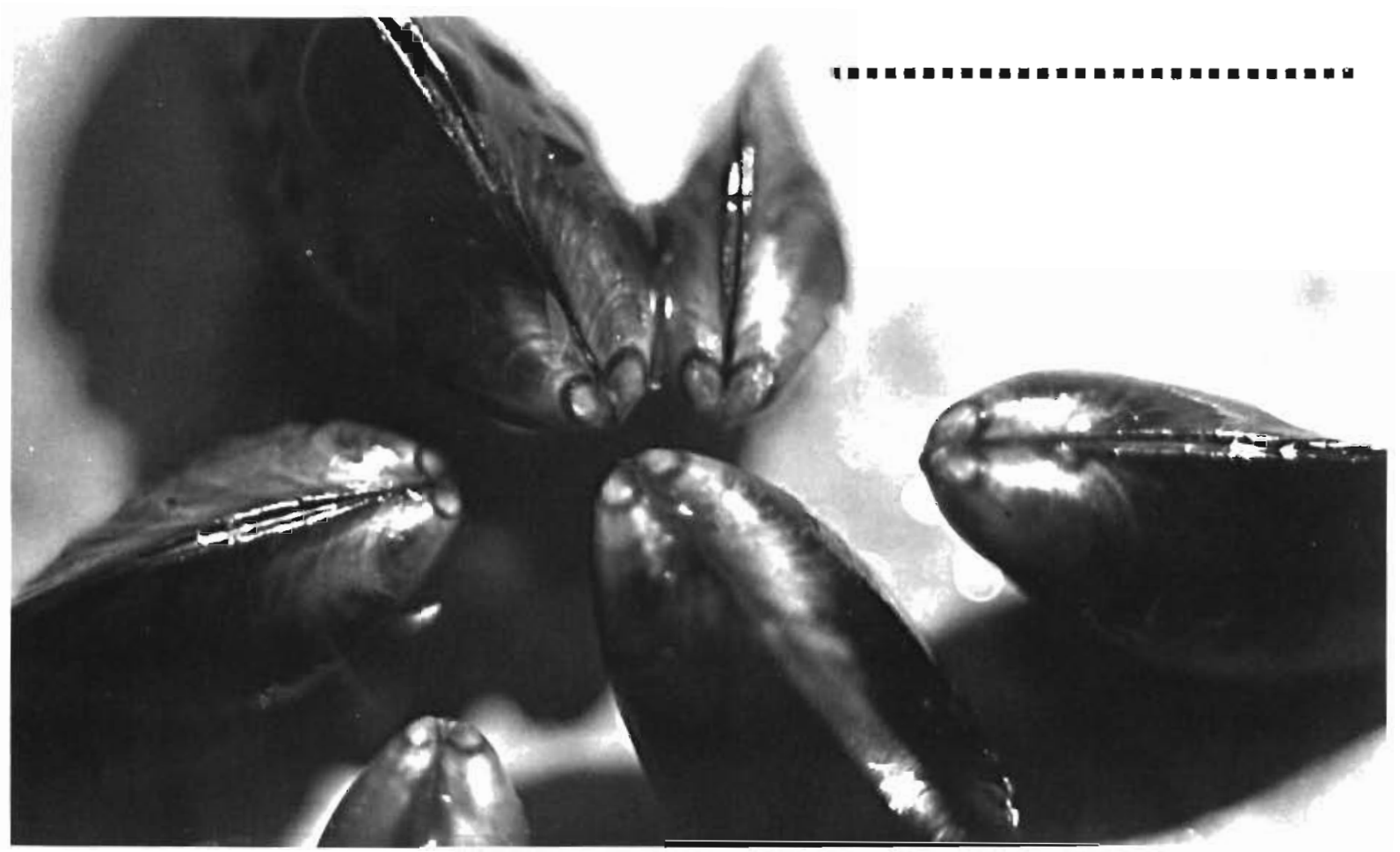

Fig. 3. Mytilus edulis. Tagged mussels ( 7.0 to $10.0 \mathrm{~mm}$ length) which had been transplanted to Tomales Bay $30 \mathrm{~d}$ earlier at a size of $1.0 \mathrm{~mm}$. Bar $=7.0 \mathrm{~mm}$

a blue pigment band in the prismatic shell layer. Together, these pigments produced the typical black color of Mytilus edulis. The bands persisted as long as the umbo shell resisted erosion. The longest field trial performed to date (discussed below) lasted $75 \mathrm{~d}$. No significant erosion to the bands occurred during this period.

\section{Field trial}

Fig. 4 is a size frequency histogram of the final lengths of tagged mussels retrieved after $75 \mathrm{~d}$ in Marconi Cove. The distribution is clearly bimodal. The

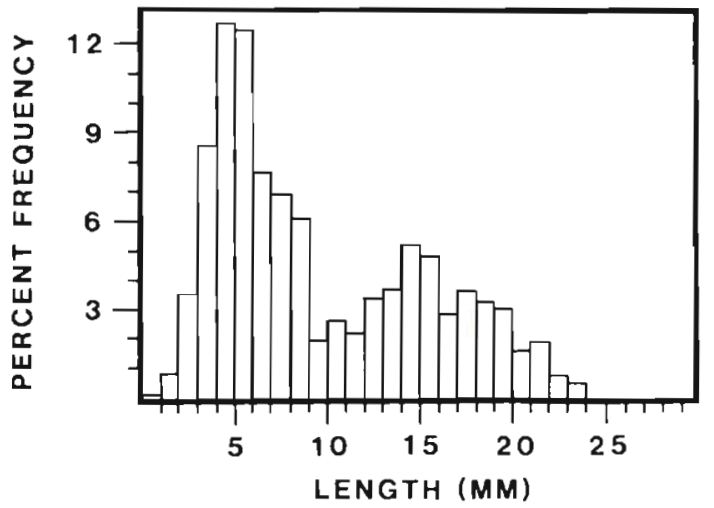

Fig. 4. Mytilus edulis. Size frequency histogram of a random sample of 809 mussels taken on Day 75 of the field trial patch of mussels was comprised of a sheet of large mussels, relatively uniform in length, with many small mussels occurring below them and in the interstices. Table 2 gives the total number and percent tagged data for Days 0 and 75, and also the percent tagged data for the small ( $\leq 10.0 \mathrm{~mm}$ ) mussels. The total number of mussels did not change significantly during the field trial (Student t-test; $t=1.28, \mathrm{df}=48, \mathrm{p}>0.2$ ) and neither did the percent tagged (G-test of independence; $G=0.6, d f=1, \quad p>0.1$, which remained approximately $83 \%$ for both the small and large modal groups.

\section{Pigmentation patterns of wild mussels}

Of the 319 wild Mytilus edulis examined, $16(5 \%)$ had bands at $\leq 1.0 \mathrm{~mm}$ from the larval umbo. Thus bands similar to those produced in the laboratory also occurred in nature, though they were rare. The degree of pigmentation of the early shell of these mussels was found to vary between different habitats, as shown in Table 3. Mussels from surface long lines in Marconi Cove were more likely to be naturally banded at $\leq 1.0 \mathrm{~mm}$ from the umbo (G-test of independence; $\mathrm{G}=5.28, \mathrm{df}=1, \mathrm{p}<0.025)$ and tended to become darker nearer to the umbo (Student t-test, variances not pooled; $\mathrm{t}=6.0, \mathrm{p}<0.001$ ) than did the raft population. The long line environment seemed less shaded than 
Table 2. Mytilus edulis. Numbers and percent tagged at the time of transplantation to Tomales Bay and $75 \mathrm{~d}$ later. A subset of the total $(n)$ was measured for length and determination of the percent tagged. Also shown is the percent of tagged mussels that were less than $10.0 \mathrm{~mm}$ in length on Day 75

\begin{tabular}{|cccc|}
\hline Day & $\begin{array}{c}\text { Total } \\
\text { number }\end{array}$ & $\begin{array}{l}\text { Percent } \\
\text { tagged }\end{array}$ & $\mathrm{n}$ \\
\hline 0 & 18739 & 83.8 & 702 \\
75 (total) & 19207 & 82.2 & 809 \\
$75(<10.0 \mathrm{~mm})$ & - & 84.2 & 492 \\
\hline
\end{tabular}

did the raft environment. When the mussels from all the different habitats sampled were pooled, the mean length $( \pm \mathrm{SD})$ of unpigmented shell was $1.9 \pm 1.5 \mathrm{~mm}$.

\section{DISCUSSION}

Expt 1 showed that, for post-larvae less than 1.5 to $3.0 \mathrm{~mm}$ in length, light is needed to induce the deposition of both the periostracal and prismatic pigments. This result was consistently seen in the 20 routine tagging trials of 7 different batches of post-larvae. The production of shell pigmentation could be turned on and off by varying the light intensity. After a length of approximately $3 \mathrm{~mm}$ is reached, the role of light on pigmentation becomes less dramatic since some pigmentation occurs at this length in nearly complete darkness. Seed (1969) showed however that light can continue to exert an effect on the intensity of pigmentation up to a length of a least $23 \mathrm{~mm}$.

Genetics also plays an important role in the shell color of Mytilus edulis. The crossing experiments of Innes \& Haley (1977) showed that genotypic, rather than environmental differences, were responsible for the production of a light brown morph of $M$. edulis. This brown morph, which is absent from our area, was not investigated in our study. Thus it is not yet known how light affects the expression of color in this morph.

Table 3. Mytilus edulis. Comparison of pigment patterns of wild mussels from 2 habitats in the same cove. Mean distances $( \pm S D)$ from the larval umbo to the first band of pigmentation in the prismatic shell layer are given as well as number of mussels that had pigment bands $\leq 1.0 \mathrm{~mm}$ from the larval umbo

\begin{tabular}{|lccc|} 
Habitat & $\begin{array}{c}\text { Distance to 1st } \\
\text { pigmentation } \\
( \pm \text { SD) }(\mathrm{mm})\end{array}$ & $\begin{array}{c}\text { No. with bands } \\
\leq 1.0 \mathrm{~mm} \text { from } \\
\text { umbo }\end{array}$ & $\mathrm{n}$ \\
\hline Long lines & $1.00 \pm 1.04$ & 8 & 88 \\
Raft & $2.92 \pm 2.33$ & 0 & 61 \\
\hline
\end{tabular}

It seems likely, however, that light will affect the intensity of expression of the individual mussel's genetically determined pigments.

The effects of light observed in the laboratory were not fully examined in experimental field studies. However, we believe that natural sunlight does produce similar effects. When post-larvae were transplanted to surface waters of Tomales Bay during periods of bright, sunny weather, it was noticed that they produced intensely pigmented shell. This observation suggests that natural sunlight does in fact cause the pigmentation response. This would not be surprising since the intensity of the incident sunlight is often greater than 175000 lux, far in excess of that used to tag mussels in the laboratory (11000 to 16000 lux). It is likely that light intensities greater than 16000 lux would produce better tags, though this has not been investigated.

From our observations, it can be predicted that the early shell of wild mussels should provide a record of the light environment encountered by those individuals near the time of recruitment. From the comparison of mussels from the long line versus the raft (Table 3), it is clear that this early light environment is variable, reflecting the variability in microhabitats chosen by recruiting larvae or post-larvae. The under-raft habitat was probably more shady than was the long line habitat. On the whole however, the pooled data showed that wild Mytilus edulis spent their early postsettlement days in shaded environments since, on average, the first $1.8 \mathrm{~mm}$ of shell was unpigmented. This is consistent with the work of Bayne (1964) which showed that crawling pediveligers were strongly negatively phototactic. The well-known preference of pediveligers and early post-larvae for filamentous or highly rugose substrata (DeBlok \& Geelen 1958) would also tend to concentrate these individuals in shady microhabitats.

The chemical structures of the pigments in mussel shells are still unclear. The reddish-brown periostracal pigment is probably a melanin, sclerotin, or possibly an ommochrome (Fox 1983). Less can be said of the blue prismatic pigment. For the post-larvae, these pigments may serve to block out UV irradiation which is well known to cause mutations and tissue damage (reviewed by Porter 1967). Mitton (1977) investigated shell color in Mytilus edulis and its adaptive significance. He found that of 2 color morphs of mussels which co-occur on the eastern seaboard of the United States, the less pigmented morph was more abundant in warmer latitudes, while in colder environments the dark morph predominated. In addition, under controlled conditions, the dark-shelled morph absorbed significantly more heat and attained higher internal temperatures than did the less pigmented phenotype. The differential occurrence of these 2 genetic color morphs 
could thus be explained by their differential rates of heat absorption. For instance, where death due to freezing was a common threat, the darker-shelled morph would have an advantage.

In contrast to Mitton's study, the present study showed that shell pigmentation of post-larvae was greatest when light intensity was greatest. Thus Mitton's cold protection hypothesis does not seem to apply to this post-larval pigmentation phenomenon which is better explained by a hypothesis of inducible UV light protection. In the absence of bright light, the shell pigments are not needed at all and the post-larva may redirect the energy and materials needed to produce these pigments into other physiological functions, such as growth.

Expt 1 showed that post-larval growth in the light was slower than in the dark. It is well known that light has an inhibitory effect on growth in Mytilus edulis. Although an earlier study (Dodd 1969) gave contradictory results, Nielsen \& Stromgren (1985) showed clearly that as long as food is not severely limiting, growth is enhanced by darkness. They found that growth in darkness was 20\% greater than that in bright natural sunlight. This figure agrees well with ours of $20.5 \%$ for continuous fluorescent light. Thus our study on small post-larvae extends the earlier work which was focused on larger mussels. Light probably reduces growth rate by inhibiting ingestion rate (Nielsen \& Stromgren 1985). For the post-larvae, growth may be further inhibited by light if the darkly pigmented shell produced under bright light is energetically more costly than clear shell.

The tagging procedure described in this study can thus be expected to inhibit growth rate slightly. However since this effect was shown to be eliminated upon removal of the post-larvae from light (Table 1), the tagging procedure should not have any permanent effect on growth. Likewise, no effect of the tag on subsequent survival was found in either the laboratory or the field (Expt 2; Table 2). Finally, the tag is persistent enough for field studies of durations on the order of months. After several years, however, the umbos of mussels can become eroded, especially in exposed environments (pers. obs.).

A potential complication of the light banding procedure is that individuals with a 'tag' do occur occasionally in nature, particularly in environments having high light intensities. The highest occurrence found here was $9 \%$ in the surface long line habitat. In most of these wild 'tagged' mussels, the band occurred randomly from 0.3 to $1.0 \mathrm{~mm}$ from the umbo and was usually closely followed by more bands of dark pigmentation. Thus, by producing a pigment band at a narrowly defined position (e.g. 0.6 to $0.8 \mathrm{~mm}$ ) and by producing a relatively broad band of unpigmented shell after the pigment band, these hatchery-produced tags will be easier to distinguish from wild 'tags'. For most purposes however, wild 'tags' seem to be rare enough not to cause any significant errors.

Another characteristic feature of post-larval mussel shells is the terminal byssal attachment plaques and hairs shown in Fig. 1. Board (1983) suggested that these hairs developed when aggregated post-larvae attached (and subsequently detached) to each other's shells. Since the post-larvae in Expt 1 were reared in isolation from one another, each individual must have produced its own set of these projecting byssal hairs. Ockelmann (1983) verified that for Mytilus sp. and Modiolus sp. at least, these projections were in fact byssal hairs, secreted by the foot, rather than the mantle. Hair-like projections occur on many other mytilids and are often very pronounced. Bottjer \& Carter (1980) showed that in Modiolus rectus these hairs have a sensory function. They can also serve to repel predators, such as drilling gastropods, as was shown for Modiolus modiolus (Wright \& Francis 1984).

The field trial (Fig. 4; Table 2) gave an example of how the tag can be used to help interpret data. Since percent tagged did not change significantly during the course of the experiment, the bimodal peak could not be attributed to new recruitment. The density of mussels in this patch was high $\left(41 \mathrm{~cm}^{-2}\right)$ with larger, fast-growing mussels forming a mat, the interstices of which were occupied by the smaller, slower-growing mussels. Apparently initial differences in growth rates were further accentuated by the fast-growing mussels' ability to confine the slower-growing ones to the interstices that have less water circulation.

The optimal wavelength and intensity of light for producing the best tag needs more study. Work to date does suggest that short UV light is not necessary for the pigmentation response since the tag was elicited by light from fluorescent fixtures which were encased in clear plastic covers. These covers screen out any UV light produced. The tagging method described in this study was shown to be practical for mussel post-larvae. Its usefulness with other species remains to be tested, though a preliminary trial with oysters Crassostrea gigas was encouraging (unpubl. data).

For the ecology of most marine invertebrates, the early post-larval stage represents something of a black box. For instance, Spight (1972), working with Nucella lamellosa, quantified larval abundance (in egg cases) and yearling abundances, and from these data estimated the first year's mortality. Actual direct counts and manipulations of the small, cryptic individuals, however, was not possible. The approach of producing, tagging, and then 'seeding' early post-larvae in the natural environment may help in better understanding this inconspicuous life stage. 
Acknowledgements. The technical assistance provided by Will Borgeson, Art Hertz, Mike Brody, Kirk Hahn, Mark Snyder, Victor Chow, Greg Ruiz, Tom Suchanek, and John Richards contributed greatly to this project. Cove Mussels Co. assisted with the field work. Two anonymous reviewers helped to improve the manuscript, and their efforts are appreciated. We thank the University of California Aquaculture and Fisheries Program, the Lemer-Gray Fund for Marine Research of the American Museum of Natural History, and Sigma Xi, the Scientific Research Society (to G.A.T.) for their generous financial support. This work is also a result of research sponsored in part by NOAA, National Sea Grant College Program, Department of Commerce, under grant No. NA85AA-D-SG140, project No. R/A-61, through the California Sea Grant College Program (to E.S.C.). The U.S. Government is authorized to reproduce and distribute for governmental purposes.

\section{LITERATURE CITED}

Bayne, B. L. (1964). The responses of the larvae of Mytilus edulis $\mathrm{L}$. to light and to gravity. Oikos 15: 162-174

Bayne, B. L. (1965). Growth and the delay of metamorphosis of the larvae of Mytilus edulis (L.). Ophelia 2: 1-47

Board, P. (1983). The settlement of post larval Mytilus edulis. J. mollusc. Stud. 49: 53-60

Bottjer, D. J., Carter, J. G. (1980). Functional and phylogenetic significance of projecting periostracal structures in the Bivalvia (Mollusca). J. Paleont. 54: 200-216

Chanley, P.E. (1961). Inheritance of shell markings and growth in the hard clam, Venus mercenaria. Proc. natn Shellfish. Ass. 50: 163-169

DeBlok, J. W., Geelen, H. J. (1958). The substratum required for the settling of mussels (Mytilus edulis L.). Archs nérl. Zool. 13 (Suppl.): 446-460

Dey, N. D., Bolton, E. T. (1978). Tetracycline as a bivalve shell marker. Proc. natn. Shellfish. Ass. 68: 77

Dodd, J. R. (1969). Effect of light on rate of growth of bivalves. Nature, Lond. 224: 617-618
Fox, D. L. (1983). Biochromy of the Mollusca. In: Hochachka P.W. (ed.) The Mollusca, Vol. II, Environmental biochemistry and physiology. Academic Press, New York, p. 281-304

Hidu, H., Hanks, J. E. (1968). Vital staining of mollusk shells with alizarin sodium monosulfonate. Proc. natn. Shellfish Ass. $58: 37-41$

Innes, D. J., Haley, L. E. (1977). Inheritance of a shell color polymorphism in the mussel. J. Heredity 68: 203-204

Loosanoff, V. L., Davis, H. C. (1963). Rearing of bivalve mollusks. Adv, mar. Biol. 1: 1-136

Mitton, J.B. (1977). Shell color and pattern variation in Mytilus edulis and its adaptive significance. Chesapeake Sci. 18: $387-390$

Nielsen, V. M., Stromgren, T. (1985). The effect of light on the shell length growth and defecation rate of Mytilus edulis (L.). Aquaculture 47: 205-211

Ockelmann, K. W (1983). Descriptions of mytilid species and definition of the Dacrydinae n. subfam. (Mytilacea Bivalvia). Ophelia 22: 81-123

Olsen, D. (1968). Banding patterns of Haliotis rufescens as indicators of botanical and animal succession. Biol. Bull. mar. biol. Lab., Woods Hole 134: 139-141

Porter, W. P. (1967). Solar radiation through the living body walls of vertebrates with emphasis on desert reptiles. Ecol. Monogr. 37: 273-296

Seed, R. (1969). The ecology of Mytilus eduis L. (Lamellibranchiata) on exposed rocky shores. II. Growth and mortality. Oecologia (Berl.) 3: 317-350

Spight, T.M. (1972). Patterns of change in adjacent populations of an intertidal snail, Thais lamellosa. Ph.D. dissertation, University of Washington

Tegner, M. (1987). Abalone seeding. In: Hahn, K. O. (ed.) Handbook of the culture of abalone and other gastropods. CRC Press, Boca Raton (in press)

Trevelyan, G. A., Chang, E. S. (1983). Experiments on larval rearing of the California mussel (Mytilus californianus). J. World Maricuit. Soc. 14: 137-148

Wright, M. M., Francis, L. (1984). Predator deterrence by flexible shell extensions of the horse mussel Modiolus modiolus. Veliger 27: 140-142 